\title{
Accelerated erosion of saltmarshes infested by the non-native burrowing crustacean Sphaeroma quoianum
}

\author{
Timothy M. Davidson*, Catherine E. de Rivera \\ Aquatic Bioinvasion Research and Policy Institute, Environmental Science \& Management Program, \\ Portland State University, PO Box 751, Portland, Oregon 97207, USA
}

\begin{abstract}
Lateral erosion of saltmarshes is affected by many abiotic and biotic factors. While abiotic factors are typically regarded as primary drivers of erosion, biotic influences such as burrowing or bioturbating taxa can also extensively modify the physical structure of this marine habitat. Many estuaries on the Pacific coast of North America have been invaded by populations of the burrowing non-native isopod Sphaeroma quoianum, which are thought to exacerbate the erosion of saltmarshes. We conducted a mensurative experiment to examine the relationship between populations of $S$. quoianum and lateral erosion rate of saltmarshes in Coos Bay, Oregon, USA. After 1 yr, we measured higher lateral erosion rates, more undercutting, and higher numbers of calved and slumped marsh sections in marsh sites infested by $S$. quoianum than in uninfested sites. This effect was also consistent at smaller spatial scales: we found lateral erosion was $300 \%$ higher in burrowed areas than in adjacent (within approx. $1 \mathrm{~m}$ ) unburrowed areas within infested sites. Our results suggest that the prodigious burrowing by dense populations of $S$. quoianum can accelerate erosion rates in saltmarshes and are substantial geomorphic agents of change in estuaries on the Pacific coast of North America.
\end{abstract}

KEY WORDS: Erosion · Ecosystem engineering $\cdot$ Biogeomorphology $\cdot$ Bioturbation $\cdot$ Biological invasions $\cdot$ Saltmarshes $\cdot$ Sphaeroma quoianum

Resale or republication not permitted without written consent of the publisher

\section{INTRODUCTION}

When the rate of erosion outpaces accretion, nearshore habitats can be greatly altered and in extreme cases, even be converted from one habitat to another (Redfield 1972, Semeniuk 1980, Hutchings 1986). In northwest Australia, high rates of erosion converted dense mangrove forest to tidal flats (Semeniuk 1980). Similarly, bioerosion can exceed coral growth and eventually degrade entire reefs into rubble and sand (Hutchings 1986). Grazing by prolific populations of littorine snails combined with climate stressors in the Gulf of Mexico caused an expansive die-off of saltmarshes and consequent conversion to mudflats (Silliman et al. 2005). While erosion and accretion are natural cyclic processes in tidal marshes (reviewed by
Singh Chauhan 2009), anthropogenic changes (e.g. hydrology, land use, sediment load, etc.) and the translocation of non-native burrowing species may accelerate erosion of saltmarshes (Talley et al. 2001, Masselink \& Hughes 2003, Soomere 2005).

Lateral erosion in saltmarshes is influenced by numerous factors. Abiotic processes are typically regarded as primary drivers of erosion in many systems (Grant 1983, Butler 1995, Widdows \& Brinsley 2002). Rainfall (Pilditch et al. 2008), sediment characteristics (water, organic and sand content; Meadows \& Tait 1989, Feagin et al. 2009), water velocity (Sgro et al. 2005), and size and direction of tidal prism (Redfield 1972), all strongly influence the rate of erosion. Biotic agents, however, can also substantially influence erosion rates, particularly burrowers/bioturbators, 
consumers, or biostabilizers (Belanger \& Bedard 1994, Butler 1995, Widdows et al. 2000, Paramor \& Hughes 2004, Jefferies et al. 2006, Escapa et al. 2007).

Burrowers/bioturbators and consumers both can greatly increase the rate of erosion of marshes. Fauna directly reduce the stability of the sediment and accelerate erosion through trampling, burrowing, bioturbation, or other forms of physical disturbance (Dionne 1985, Talley et al. 2001, Escapa et al. 2007). Burrowing by the crab Chasmagnathus granulatus decreases sediment shear strength and increases the erosion rate of saltmarshes in Argentina (Escapa et al. 2007). Dionne (1985) observed extensive marsh erosion from trampling and foraging by geese in Quebec. Furthermore, bioturbation by increasing densities of Manila clams resulted in an exponential increase of sediment erosion in flume experiments (Sgro et al. 2005). Herbivores indirectly accelerate erosion by reducing the abundances of sediment biostabilizers. For example, herbivory and bioturbation by the polychaeate Nereis diversicolor reduces the abundance of marsh plants leading to increased erosion in marshes (Paramor \& Hughes 2004). The presence of the diatom-grazing amphipod Corophium volutator significantly decreases sediment shear strength (Gerdol \& Hughes 1994) and increases erosion rates (Widdows et al. 2009) in marsh sediment.

On the Pacific coast of North America, over $93 \%$ of salt marshes have been lost as a result of human activities (Bromberg Gedan \& Silliman 2009). The introduction of the non-native burrowing isopod (Sphaeroma quoianum) on the Pacific coast adds yet another stressor to the remaining saltmarshes. S. quoianum was first introduced to San Francisco Bay, California in the Gold Rush era from its native habitat of Australia and New Zealand (Rotramel 1972, Carlton 1979). This temperate wood-boring isopod then spread through ship fouling or boring (Carlton 1979) to at least 14 other estuaries on the Pacific coast of North America from Baja California to Yaquina Bay, Oregon (Davidson 2008). In many marshes, isopods perforate marsh banks with burrows and increased densities may increase rates of erosion (Carlton 1979, Talley et al. 2001); however, in its native range of Australia, S. quoianum does not appear to inhabit marsh banks in high densities and its erosive effects are likely limited (Davidson et al. 2008). Lateral erosion rates are high in locations infested by S. quoianum (Carlton 1979, Talley et al. 2001, Davidson 2008), but uninfested locations were not available to isolate the isopod effects from the other factors affecting erosion. Since numerous factors may confound or obscure the effect of burrowing by $S$. quoianum on erosion, it is not surprising that other studies did not detect a relationship between burrows/isopod densities and erosion rate (Bane 2002) or detected relationships only at certain times or locations (Talley et al. 2001). A short-term (4 wk) transplantation experiment revealed that the initial excavation of burrows by $S$. quoianum could increase sediment removal by $240 \%$ compared to controls (Talley et al. 2001), but longer-term testing of mechanisms and these associations is still needed.

Populations of isopods have extensively invaded the saltmarshes of Coos Bay, Oregon, but perhaps since it is a relatively new invasion (discovered in 1995; Carlton 1996), isopods occur in patchy distributions both between marshes and within infested marshes. We build on the earlier studies by measuring erosion in and among the discrete isopod aggregations in Coos Bay. This natural 'experiment' with different levels of infestation within and between marshes helps isolate the effects of burrowing by isopods from the other factors affecting erosion rates. To examine the relationship between the presence of populations of isopods and lateral erosion rates in the field, we conducted a field study at 2 scales. This research seeks to quantify the erosive impact of burrows between infested and uninfested saltmarshes (at a scale of tens to hundreds of meters) and between burrowed and unburrowed areas within infested marshes (at centimeters to meter scale). Within infested marshes, burrows can completely cover marsh banks (near $100 \%$ cover) but often burrows appear in patchy distributions. We hypothesized that (1) marsh sites infested by populations of Sphaeroma quoianum will experience more erosion than uninfested marsh sites, and (2) within infested marsh sites, areas with patches of burrows will erode faster than areas without burrows. Hence, the results of this research will elucidate the effects of a nonnative burrowing crustacean on critical estuarine habitat and, more broadly, will identify whether and to what extent relatively small, yet densely aggregated infauna can influence erosion in marshes.

\section{MATERIALS AND METHODS}

We examined the relationship between burrows of Sphaeroma quoianum and lateral erosion rate of marsh banks (embankments composed of mud, clay and/or peat) in sites infested with populations of $S$. quoianum (hereafter: infested sites, $\mathrm{n}=13$ ) and sites without substantial populations (cover of burrows $<5 \%$ ) of $S$. quoianum (hereafter: uninfested sites, $\mathrm{n}=12$ ) in Coos Bay, Oregon, USA $\left(43.416^{\circ} \mathrm{N}, 124.219^{\circ} \mathrm{W}\right)$. We define sites as stretches of marsh banks $50 \mathrm{~m}$ in length and separated from other sites by at least $150 \mathrm{~m}$, but often much more (except for 2 sites that were only $85 \mathrm{~m}$ apart from each other). Experimental sites were selected haphazardly based on accessibility and pres- 
ence (infested) or absence (uninfested) of isopods in a variety of marshes in the Coos Bay estuary (including one uninfested site in the South Slough National Estuarine Research Reserve). Some uninfested sites were visited but not selected because they visibly differed in site attributes from the infested sites (e.g. sloping marshes lacking a vertical bank). Both types of sites spanned the entire Coos Bay estuary, including tidal creeks, bay fronts, and sloughs and ranged across 5 to 32 PSU.

We examined erosion in marsh sites by measuring lateral erosion over $1 \mathrm{yr}$ and by measuring indicators of bank erosion (Fig. 1). In each infested site, we inserted 20 erosion pins (wire pins, $53.3 \mathrm{~cm}$ long) into marsh banks perpendicular to the bank. Half of the pins (10) were randomly placed in burrowed areas ('areas' are subsets of infested sites; mean $\pm 95 \% \mathrm{CI}$ : $18 \pm 2$ burrows per $100 \mathrm{~cm}^{2}$ ) and half were randomly placed in adjacent unburrowed areas (mean $\pm 95 \%$ CI: $0.40 \pm$ 0.21 burrows per $100 \mathrm{~cm}^{2}$ ). Each unburrowed pin was paired with a burrowed pin within approximately $1 \mathrm{~m}$ and placed at similar tidal heights. Ten erosion pins were planted per uninfested site to compare erosion rates between infested and uninfested sites. After $1 \mathrm{yr}$, we returned and measured the length of the exposed section of the erosion pin. We also counted the number of burrows within a $6 \mathrm{~cm}$ radius from the erosion pins to determine burrow density and estimated burrow percent cover at 10 randomly placed quadrats $\left(0.25 \mathrm{~m}^{2}\right)$ in each site.

In both infested and uninfested sites, we also estimated the amount of lateral erosion by placing onshore wooden reference stakes $1.25 \mathrm{~m}$ from the marsh edge in 10 random locations per site (thus 10 measurements

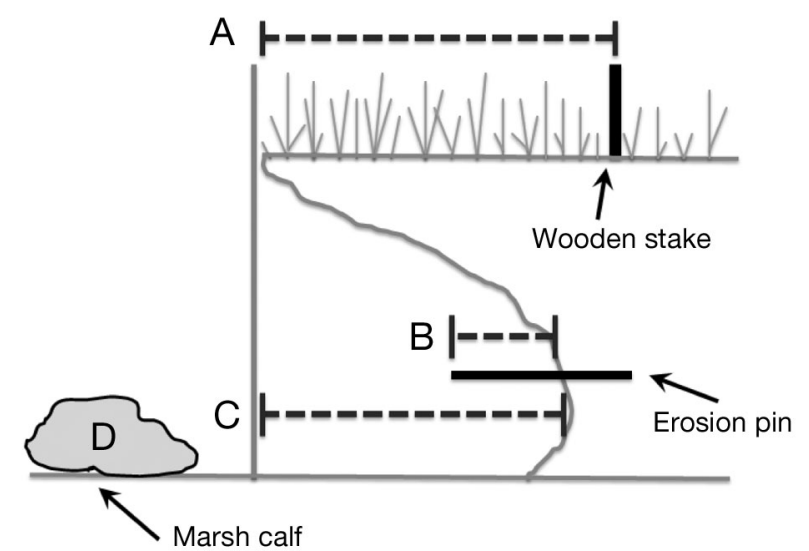

Fig. 1. Methods used to measure lateral erosion and indicators of bank erosion in marsh sites (side view). (A) Distance between wooden stake reference markers and the edge of the marsh (denoted by a gray line perpendicular to the marsh), (B) distance between the end of an erosion pin and marsh bank, (C) maximum distance between the marsh edge and marsh bank, and (D) the number of marsh calves and slumped sections present at the end of the experiment per site). The change in the distance between the stakes and marsh edge were measured after $1 \mathrm{yr}$ to estimate erosion rate. We also determined the maximum undercutting of the marsh bank in 10 random locations in each site at the end of the experiment. Undercutting was measured by holding a pole perpendicular (vertical) to the marsh edge and measuring the maximum horizontal distance between the pole and the bank. In some sites, the banks sloped outwards towards the bottom and in these cases we measured the distance from the bottom of the slope to the marsh edge (recorded as negative undercutting). In all sites, we counted the number of slumped and calved marsh bank sections following erosion monitoring.

We collected sediment cores to compare the percentages of water, sand, and organic matter between infested and uninfested sites and between burrowed and unburrowed areas where erosion pins were planted. We also recorded characteristics of the site including the relative amount of water movement (by measuring the dissolution of calcium-sulfate clod cards), slope of the marsh bank, and the height of the marsh at each site (from top of the marsh to sediment below the bank). While we were unable to measure the tidal height of each erosion pin, we placed erosion pins in burrowed and unburrowed areas at various heights in the bank so our initial placement of the erosion pins did not exhibit a systematic difference in tidal height across treatments (burrowed vs. unburrowed areas). The overlying vegetation was also identified.

Statistical analyses. We tested for a difference in the erosion rate (both pins and stakes), maximum undercutting, and the number of slumped and calved marsh sections between infested and uninfested sites using a 2 sample $t$-test, Welch's $t$-test (heteroscedastic data), or Mann-Whitney test (when transformations failed to normalize the data), using the mean values from the 10 subsamples measured within site. The sediment (\% water, \% organic, \% sand) and other site characteristics (burrow density, \% cover of burrows, relative water movement, slope of the bank, marsh height) between infested and uninfested sites and between burrowed and unburrowed areas within infested sites were tested in the same fashion. Since our erosion data sometimes included negative values (representing accretion or a sloped bank), we added the minimum values to the respective dataset to allow transformation $[\sqrt{ } \mathrm{x}$ or $\log (\mathrm{x})]$. We used a 2-way ANOVA to test if the mean erosion rate in burrowed and unburrowed areas differed (treatment factor, fixed) and if the mean erosion rate differed between infested sites (site factor, random). Assumptions of all statistical tests were visually evaluated using boxplots, QQ-plots, and frequency histograms. Transformations failed to normalize the data and eliminate 
heteroscedacity between burrowed and unburrowed erosion rates, so we analyzed the raw data and relied on the robustness of ANOVA to account for the minor violations (Underwood 1981). Relationships between the sediment characteristics and the burrow density, water flow, and erosion rate were examined using Pearson correlations or Spearman's rank correlations. Degrees of freedom for our statistical tests varied due to the loss of erosion pins and stakes during the experiment.

\section{RESULTS}

\section{Erosion in infested versus uninfested marsh sites}

Three of four measures of erosion were significantly higher in saltmarsh sites infested by populations of Sphaeroma quoianum than in uninfested marsh sites (Fig. 2). Infested sites exhibited higher mean erosion rates as measured by erosion pins, higher mean under-
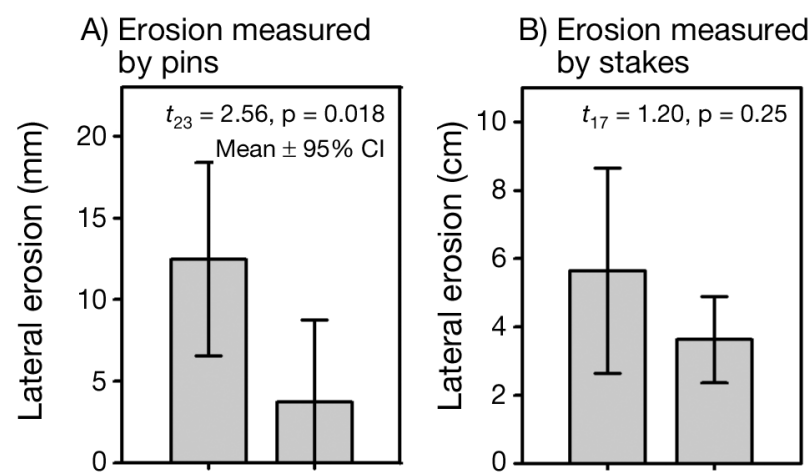

C) Maximum undercutting
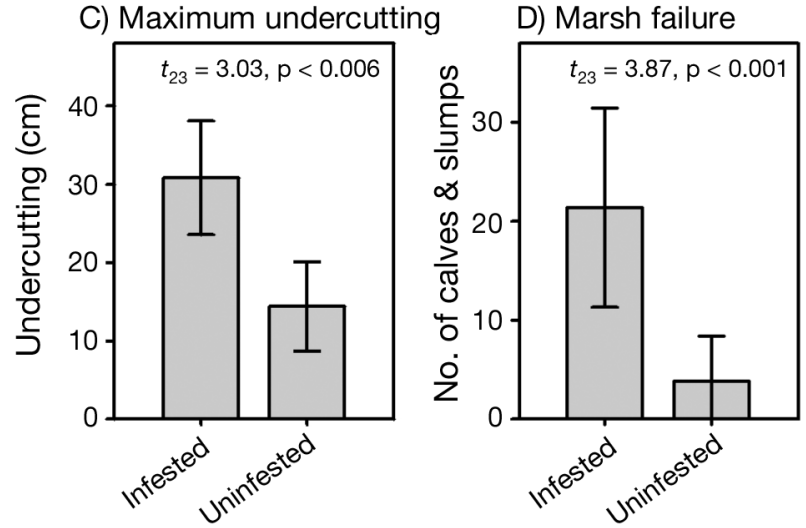

Fig. 2. Lateral saltmarsh erosion measured by (A) erosion pins, (B) onshore reference markers (wooden stakes), (C) maximum undercutting and (D) marsh failure in marshes infested versus uninfested by populations of the burrowing isopod Sphaeroma quoianum. Bars show mean $\pm 95 \% \mathrm{CI}_{\text {; }}$ $\mathrm{n}=13$ for infested sites, $\mathrm{n}=12$ for uninfested sites. Degrees of freedom varied due to the use of different analyses: 2-sample $t$-test (A, C, D) or Welch's 2-sample t-test (B) cutting values, and more evidence of marsh failure/breakage (more slumped and calved areas of marshes) than uninfested marshes. Infested sites had higher, but not significantly higher, erosion rates than uninfested sites when erosion was measured by onshore reference stakes (Fig. 2B). Estimates of erosion measured from stakes were highly variable and likely require longer-term deployment for effects to be detected. Erosion rates may also have been underestimated due to the loss of stakes when large sections of marsh failed. Maximum rates of erosion in infested areas and uninfested areas, respectively, were 165.37 and $64.52 \mathrm{~mm}$ (erosion pins), 97.5 and $67.0 \mathrm{~cm}$ (stakes), 85 and $56 \mathrm{~cm}$ (undercutting), and 57 and 28 (number of slumps and calves).

Lateral erosion was also positively correlated with burrow densities, whether erosion was measured by erosion pins $\left(\mathrm{r}^{2}=0.37, t_{23}=3.7, \mathrm{p}=0.001\right)$, undercutting $\left(\mathrm{r}^{2}=0.50, t_{23}=4.8, \mathrm{p}=0.001\right)$, or the number of slumps and calves $\left(\mathrm{r}^{2}=0.23, t_{23}=2.6, \mathrm{p}=0.001\right)$ in marshes. However, we did not detect a significant correlation between burrow density and erosion measured through reference stakes $\left(\mathrm{r}^{2}=0.12, t_{22}=1.71, \mathrm{p}=\right.$ $0.10)$.

\section{Erosion in burrowed versus adjacent unburrowed areas of infested marshes}

Within infested marshes, the mean lateral erosion rate was 3 times greater in burrowed areas than adjacent unburrowed areas $\left(F_{1,12}=33.08, p=0.001\right.$, Fig. 3$)$. Maximum erosion in burrowed and unburrowed areas was 165.37 and $79.08 \mathrm{~mm}$, respectively. The rate of erosion also varied between sites $\left(F_{1,12}=5.6, \mathrm{p}=0.001\right)$ but the effect of burrows was consistent across all sites (Treatment $\times$ Site interaction, $F_{12,208}=1.0, \mathrm{p}=0.45$ ) . Lateral erosion and burrow density were also positively correlated $\left(\mathrm{r}^{2}=0.50, t_{24}=4.9, \mathrm{p}=0.001\right)$ within infested sites. The estimates of erosion were likely conservative since some pins were lost in the sites when large sections of marsh bank collapsed. In addition, isopods colonized or increased burrow density in $22.2 \%$ of the unburrowed areas we monitored, which suggests many of the unburrowed habitats examined are suitable for isopods.

\section{Habitat characteristics}

In addition to erosion rates, infested and uninfested marshes differed significantly in burrow densities and $\%$ cover and in the mean height of the marshes (Table 1). The other measured factors (\% water, $\%$ organics, \% sand, slope, and water movement) have 


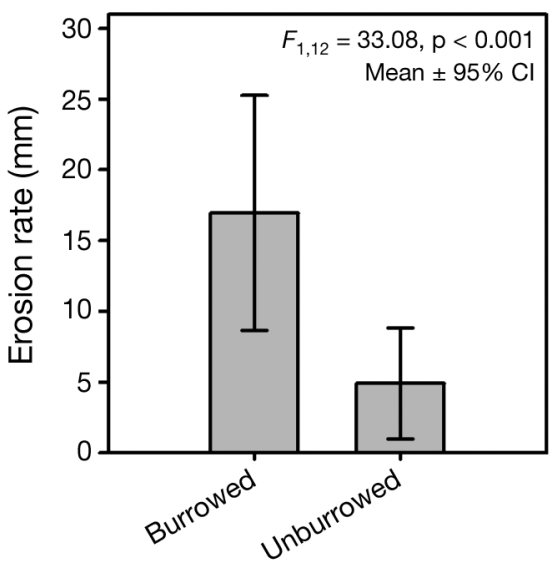

Fig. 3. Lateral erosion (measured by paired erosion pins) in burrowed and unburrowed areas within marsh banks infested by Sphaeroma quoianum. Bars show means $\pm 95 \%$ $\mathrm{CI} ; \mathrm{n}=13$

similar values and we did not detect a significant difference in those factors between infested and uninfested sites. The mean percentage of sand in uninfested marsh sediment was higher than in infested marshes but was also highly variable across sites. Similarly, the other sediment characteristics and slope of the marsh bank in burrowed areas did not significantly differ from unburrowed areas (Table 1). The vegetation type did not vary consistently between sites; most sites were dominated by Salicornia virginica and Carex lyngbyei. Other marsh plants and algae were present in varying densities including Deschampsia caespitosa, Distichlis spicata, Jaumea carnosa, Scirpus sp., Ulva sp. and Fucus gardneri.

\section{DISCUSSION}

The physical modification of substrata by animals can alter the structure and function of many marine habitats. These physical effects are especially acute in habitats where dense aggregations of animals, such as burrowers, erode substrata. In Coos Bay, Oregon, we demonstrated that the saltmarshes infested by populations of the non-native burrowing isopod Sphaeroma quoianum experience higher rates of erosion, are more undercut, and experienced more slumping and calving than uninfested marsh sites. While burrowing animals that create larger burrows have been associated directly with erosion and shoreline loss, for example Chinese mitten crabs (Dutton \& Conroy 1998), grapsid crabs (Escapa et al. 2007), and beavers, nutria, and other mammals (Butler 1995, Linscombe \& Kinler 1997 , Meyer 2006), our study suggests that small burrowing organisms, when in dense aggregations, can also accelerate erosion and have appreciable physical effects on saltmarshes. Studies have also documented the physical effects of dense aggregations of small fauna to other wetland habitats. In simulated tidal flats, increasing densities of small Manila clams (Venerupis philippinarum, $30 \mathrm{~mm}$ ) and mud snails (Hydrobia ulvae, 2 to $4.5 \mathrm{~mm}$ ) caused an exponential increase in sediment erosion (Sgro et al. 2005, Orvain et al. 2006). Feeding by swarms of mysids also promotes sediment suspension and erosion (Roast et al. 2004). Similarly, prodigious burrowing by aggregations of small sphaeromatid isopods in mangroves destroys the aerial roots used to stabilize the trees and alters their morphology (Rehm \& Humm 1973, Brooks \& Bell 2002). Thus, aggregations of small burrowers and bioturba-

Table 1. Site and sediment characteristics between sites infested and uninfested by populations of Sphaeroma quoianum and burrowed and unburrowed areas within infested sites. Values are presented as means $\pm 95 \%$ CI. Bold text denotes statistically significant differences between means. Degrees of freedom for $t$-tests are shown in parentheses

\begin{tabular}{|c|c|c|c|c|c|c|c|c|}
\hline \multirow{3}{*}{ Burrow density (\# 0.25m-2) } & \multirow{3}{*}{$\begin{array}{l}\text { Infested } \\
194.5 \pm 29.6\end{array}$} & \multirow{3}{*}{$\begin{array}{c}\text { Site } \\
\text { Uninfested } \\
5.8 \pm 6.1\end{array}$} & \multirow{3}{*}{$\begin{array}{l}\text { Value of } \\
\text { test statistic }\end{array}$} & \multirow{3}{*}{$\begin{array}{c}\mathrm{p} \\
<0.001\end{array}$} & \multirow{3}{*}{$\begin{array}{l}\overline{\text { Burrowed }} \\
\mathrm{365.5 \pm 52.8}\end{array}$} & \multirow{3}{*}{$\begin{array}{l}\text { eas within inf } \\
\text { Unburrowed } \\
27.0 \pm 14.2\end{array}$} & \multirow{3}{*}{$\begin{array}{c}\text { Ealue of } \\
\text { Valued sites } \\
\text { test statistic } \\
\mathbf{1 6 9}^{\mathrm{a}}\end{array}$} & \multirow{3}{*}{$\begin{array}{c}\mathrm{p} \\
<0.001\end{array}$} \\
\hline & & & & & & & & \\
\hline & & & & & & & & \\
\hline$\%$ cover of burrows & $43.9 \pm 7.7$ & $1.4 \pm 1.5$ & $144^{\mathrm{a}}$ & $<0.001$ & - & - & - & - \\
\hline$\%$ water & $53.5 \pm 2.9$ & $52.5 \pm 5.0$ & $0.33^{\mathrm{b}}(23)$ & 0.74 & $53.7 \pm 3.0$ & $53.2 \pm 3.1$ & $0.21^{\mathrm{b}}(24)$ & 0.84 \\
\hline$\%$ organics & $11.0 \pm 1.4$ & $10.4 \pm 1.6$ & $0.61^{\mathrm{b}}(23)$ & 0.55 & $11.4 \pm 1.5$ & $10.7 \pm 1.5$ & $0.66^{\mathrm{b}}(24)$ & 0.52 \\
\hline$\%$ sand & $6.3 \pm 2.5$ & $23.3 \pm 14.9$ & $-1.04^{\mathrm{c}}(11)$ & 0.32 & $5.5 \pm 2.8$ & $7.0 \pm 3.5$ & $-0.71^{\mathrm{b}}(21)$ & 0.48 \\
\hline Slope $\left({ }^{\circ}\right)^{\mathrm{d}}$ & $94.2 \pm 2.4$ & $91.9 \pm 1.8$ & $107^{\mathrm{a}}$ & 0.12 & $92.9 \pm 2.1$ & $95.4 \pm 3.4$ & $63.5^{\mathrm{a}}$ & 0.29 \\
\hline Water movement ${ }^{\mathrm{e}}$ & $4.2 \pm 1.1$ & $3.7 \pm 1.1$ & $1.01^{\mathrm{b}}(23)$ & 0.32 & - & - & - & - \\
\hline Marsh height (m) & $1.3 \pm 0.3$ & $0.7 \pm 0.2$ & $3.83^{b}(23)$ & $<0.001$ & - & - & - & - \\
\hline \multicolumn{9}{|c|}{ 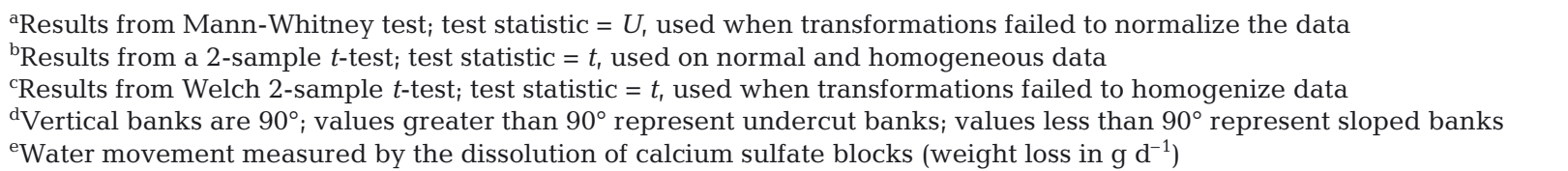 } \\
\hline
\end{tabular}


tors can have substantial erosive effects on wetland habitats; the loss of which could negatively affect the many species that depend on wetlands for food and refuge (Boesch \& Turner 1984).

While the initial excavation of burrows removes a relatively small volume of the outer areas of marshes (Talley et al. 2001, authors' unpubl. data), the increase in surface area from the creation of burrows may make infested sites more prone to other erosive forces, such as tidal action. Previous experiments revealed that low densities of isopods (1 isopod per $10 \mathrm{~cm}^{2}$ ) removed between $2.7-4.3 \%$ of the outer $5 \mathrm{~cm}$ of marsh sediment in under 2 mo (modified from authors' unpubl. data) and, similar to Talley et al. (2001), burrows of Sphaeroma quoianum occupied 3 to $15 \%$ of the outer $5 \mathrm{~cm}$ of sediment in burrowed areas of San Diego Bay. The creation of burrows, however, also substantially increases the exposed surface area of marsh banks: each burrow increases the mean $( \pm 95 \%$ CI) surface area by $1579 \pm 149 \%$ (burrow opening: $0.51 \pm 0.03 \mathrm{~cm}$ vs. total burrow surface area: $7.5 \pm 0.82 \mathrm{~cm}$; T. Davidson unpubl.). This increase in surface area of marsh exposed to additional erosive forces plus the active flushing of the burrows by isopods likely facilitates the removal of additional sediment through tidal action and decreases the shear strength of the bank (Talley et al. 2001). As the infested banks become more perforated by additional recruitment of isopods and as the interiors of the preexisting burrows are continuously washed away, the marsh bank is weakened and experiences more lateral erosion and undercutting. Eventually, the bank collapses when the undercut portion succumbs to gravity (Redfield 1972, Gabet 1998) leading to the characteristic slumped and calved sections of marsh present in many sites infested by $S$. quoianum (Carlton 1979, Talley et al. 2001).

The positive association between burrows of Sphaeroma quoianum and erosion were also consistent across both spatial scales: between marsh sites (tens to hundreds of meters scale) and within infested sites (centimeters to meter scale). This suggests that isopod burrowing may have a direct localized erosive effect but also that their erosive effects on a small scale may contribute indirectly to erosion on larger scales by facilitating wave and tidally-induced erosion. Within infested sites, even small patches of burrows experienced lateral erosion rates $300 \%$ higher than adjacent unburrowed areas. Our results are consistent with results from Talley et al. (2001) who showed that densely burrowed areas exhibited lower sediment shear strengths and more undercutting. They also found isopods in experimental enclosures could remove up to $240 \%$ more sediment compared to the removal in unpopulated controls. Our experiment examines the continuing association between isopod burrows and erosion rate following the initial erosive effect of excavating burrows. The results of comparing burrowed and unburrowed areas and sites in numerous estuarine locations suggest that the erosive effects continue after the isopod establishes its burrow.

While our study design is mensurative, it is replicated across a variety of locations within the Coos Bay estuary, and our results are consistent with anecdotal observations from other Pacific coast estuaries (Talley et al. 2001). We did not detect systematic differences between infested and uninfested sites, except that marshes on infested sites were typically taller than on uninfested sites. This may have 2 potential confounding effects: taller marshes might have more available space for isopods and harbor more isopods or taller marshes may have more area exposed to erosive forces. We recognize additional unmeasured factors may also affect erosion rate. The additional factors that affect erosion likely caused the high observed variability in erosion between the sites. By also examining the effect of burrows on erosion rate at a scale of less than $1 \mathrm{~m}$, we attempted to separate the effect of burrows from the other factors that affect erosion in an estuary. However, even if unmeasured factors affected the results, it is highly unlikely that those factors varied consistently across all measured sites and measured locations within sites. Thus, it appears unlikely that an unmeasured factor could consistently confound our results within centimeter scales. An alternative hypothesis for our results could be that isopods colonize areas that already exhibit high rates of erosion. That hypothesis seems unlikely because (1) during the course of the study isopods colonized several of the previously unburrowed areas that served as our reference areas, (2) maintaining a burrow in dynamic areas with high erosion would require constant attention and be energetically expensive, and (3) isopods can suffer mortality when weak, unstable areas erode, collapse, or slump (T. Davidson pers. obs.). Isopods, like other burrowing crustaceans, appear to prefer burrowing in more solid sediments (Jones \& Simon 1981, Wang et al. 2009, T. Davidson pers. obs.). In addition, the perceived benefits of settling in highly erosional environments (increased flushing of wastes, food) are likely not as important for a filter feeder that constantly exchanges the water that enters and leaves the burrow (Rotramel 1975). Thus, we hypothesize that isopods will preferentially colonize substrata that are stable and not prone to collapse. Future studies should examine the factors that affect colonization by this nonnative species.

Saltmarshes are dynamic habitats prone to cyclic patterns of erosion and accretion (Redfield 1972, Gabet 1998, Singh Chauhan 2009). However, anthropogenic changes in hydrology, land use, sediment load, and 
other factors can accelerate erosion rates and alter the physical characteristics of these habitats. Our study adds to previous studies on the biotic sources of erosion, further suggesting that small burrowing or bioturbating species can also be substantial agents of change in saltmarsh habitats. While human actions that alter wetlands are now closely regulated, the potential erosive impacts of bioeroding and bioturbating species, such as Sphaeroma quoianum, remain unmeasured and largely ignored. The widespread invasion of S. quoianum in Pacific coast estuaries and lack of effective management for this non-native species suggests that the small percentage of intact saltmarshes on the Pacific coast remain prone to erosion.

Acknowledgements. Many thanks to G. Ruiz, M. Sytsma, and other members of the Aquatic Bioinvasion Research and Policy Institute for their helpful advice. We are indebted to B. Grupe, H. Keammerer, S. Lebsack, and A. Wilson for their field assistance. Comments by 3 anonymous reviewers and L. BlissKetchum greatly improved previous versions of this manuscript. Funding for this project was provided by the Western Regional Panel on Aquatic Nuisance Species (under United States Fish \& Wildlife Service Grant Agreement number 60181-7G256 to C.E.dR.). Additional support was provided by S. Rumrill of the South Slough National Estuarine Research Reserve (field supplies), C. Young of the Oregon Institute Marine Biology (lab space), and from the Estuarine Reserves Division, Office of Ocean and Coastal Resource Management, National Ocean Service, National Oceanic and Atmospheric Administration.

\section{LITERATURE CITED}

Bane S (2002) Effects of an invasive isopod on erosion rates at Elkhorn Slough, California. MSc thesis, San Jose State University, CA

Belanger L, Bedard J (1994) Role of ice scouring and goose grubbing in marsh plant dynamics. J Ecol 82:437-445

Boesch DF, Turner RE (1984) Dependence of fishery species on salt marshes: the role of food and refuge. Estuaries 7: 460-468

Bromberg Gedan K, Silliman BR (2009) Patterns of salt marsh loss within coastal regions of North America. In: Silliman BR, Bertness, MD, Grosholz E (eds) Human impacts on salt marshes: a global perspective. University of California Press, Berkeley, CA, p 253-266

Brooks BA, Bell SS (2002) Mangrove response to attack by a root boring isopod root repair versus architectural modification. Mar Ecol Prog Ser 231:85-90

Butler DR (1995) Zoogeomorphology: animals as geomorphic agents. Cambridge University Press, New York, NY

Carlton JT (1979) History, biogeography, and ecology of the introduced marine and estuarine invertebrates of the Pacific coast of North America. PhD dissertation, University of California, Davis, CA

Carlton JT (1996) Marine bioinvasions: the alteration of marine ecosystems by nonindigenous species. Oceanography (Wash DC) 9:36-43

$>$ Davidson TM (2008) Prevalence and distribution of the introduced burrowing isopod, Sphaeroma quoianum in the intertidal zone of a temperate northeast Pacific estuary (Isopoda, Flabellifera). Crustaceana 81:155-167
Davidson TM, Hewitt CL, Campbell M (2008) Distribution, density, and habitat use among native and introduced populations of the Australasian burrowing isopod Sphaeroma quoianum. Biol Invasions 10:399-410

Dionne JC (1985) Tidal marsh erosion by geese, St. Lawrence estuary, Quebec. Géogr Phys Quatern 39:99-105

Dutton CD, Conroy C (1998) Effects of burrowing Chinese mitten crabs (Eriocheir sinensis) on the Thames Tideway. Environment Agency, London

Escapa M, Minkoff DR, Perillo GME, Iribarne O (2007) Direct and indirect effects of burrowing crab Chasmagnathus granulatus activities on erosion of southwest Atlantic Sarcocornia-dominated marshes. Limnol Oceanogr 52: 2340-2349

Feagin RA, Lozada-Bernard SM, Ravens TM, Moller I, Yeager KM, Baird AH (2009) Does vegetation prevent wave erosion of salt marsh edges? Proc Natl Acad Sci USA 106: 10109-10113

Gabet EJ (1998) Lateral migration and bank erosion in a saltmarsh tidal channel in San Francisco Bay, California. Estuaries 21:745-753

Gerdol V, Hughes RG (1994) Effect of Corophium volutator on the abundance of benthic diatoms, bacteria and sediment stability in two estuaries in southeastern England. Mar Ecol Prog Ser 114:109-115

Grant J (1983) The relative magnitude of biological and physical sediment reworking in an intertidal community. J Mar Res 41:673-689

> Hutchings PA (1986) Biological destruction of coral reefs. A review. Coral Reefs 4:239-252

Jefferies RL, Jano AP, Abraham KF (2006) A biotic agent promotes large-scale catastrophic change in the coastal marshes of Hudson Bay. J Ecol 94:234-242

Jones MB, Simon MJ (1981) Habitat preferences of two estuarine burrowing crabs Helice crassa Dana (Grapsidae) and Macrophthalmus hirtipes (Jacquinot) (Ocypodidae). J Exp Mar Biol Ecol 56:49-62

Linscombe G, Kinler N (1997) A survey of vegetative damage caused by nutria herbivory in the Barataria and Terrebonne basins. Barataria-Terrebonne National Estuary Program, Thibodaux, LA

Masselink G, Hughes MC (2003) Introduction to coastal processes and geomorphology. Hodder Arnold, London

Meadows PS, Tait J (1989) Modification of sediment permeability and shear strength by two burrowing invertebrates. Mar Biol 101:75-82

Meyer A (2006) The impacts of nutria on vegetation and erosion in Oregon. MS thesis, University of Colorado, Boulder, $\mathrm{CO}$

> Orvain F, Sauriau P, Bacher C, Prineau M (2006) The influence of sediment cohesiveness on bioturbation effects due to Hydrobia ulvae on the initial erosion of intertidal sediments: a study combining flume and model approaches. J Sea Res 55:54-73

> Paramor OAL, Hughes RG (2004) The effects of bioturbation and herbivory by the polychaete Nereis diversicolor on loss of saltmarsh in south-east England. J Appl Ecol 41: 449-463

Pilditch CA, Widdows J, Kuhn NJ, Pope ND, Brinsley BD (2008) Effects of low tide rainfall on the erodibility of intertidal cohesive sediments. Cont Shelf Res 28:1854-1865

$>$ Redfield AC (1972) Development of a New England salt marsh. Ecol Monogr 42:201-237

Rehm A, Humm HJ (1973) Sphaeroma terebrans: a threat to the mangroves of southwestern Florida. Fla Sci 182: $173-174$

Roast SD, Widdows J, Pope ND, Jones MB (2004) Sediment- 
biota interactions: mysid feeding activity enhances water turbidity and sediment erodability. Mar Ecol Prog Ser 281: $145-154$

Rotramel G (1972) Iais californica and Sphaeroma quoyanum, two symbiotic isopods introduced to California. (Isopoda: Janiridae and Sphaeromatidae). Crustaceana 13(Suppl III): 193-197

Rotramel G (1975) Filter-feeding by the marine boring isopod, Sphaeroma quoyanum H. Milne Edwards, 1840 (Isopoda, Sphaeromatidae). Crustaceana 28:7-10

Semeniuk V (1980) Mangrove zonation along an eroding coastline in King Sound, North-Western Australia. Aust J Ecol 68:789-812

Sgro L, Mistri M, Widdows J (2005) Impact of the infaunal Manila clam, Ruditapes philippinarum, on sediment stability. Hydrobiologia 550:175-182

Silliman BR, van de Koppel J, Bertness MD, Stanton L, Mendelssohn I (2005) Drought, snails, and large-scale die-off of southern U.S. salt marshes. Science 310: 1803-1806

Singh Chauhan PP (2009) Autocyclic erosion in tidal marshes. Geomorphology 110:45-57

Soomere T (2005) Fast ferry traffic as a qualitatively new forcing factor of environmental processes in non-tidal sea

Editorial responsibility: Hans Heinrich Janssen, Oldendorf/Luhe, Germany areas: a case study in Tallinn Bay, Baltic Sea. Environ Fluid Mech 5:293-323

Talley TS, Crooks JA, Levin LA (2001) Habitat utilization and alteration by the invasive burrowing isopod, Sphaeroma quoyanum, in California salt marshes. Mar Biol 138: 561-573

Underwood AJ (1981) Techniques of analysis of variance in experimental marine biology and ecology. Oceanogr Mar Biol Annu Rev 19:513-605

Wang J, Tang L, Zhang X, Wang C and others (2009) Finescale environmental heterogeneities of tidal creeks affect distribution of crab burrows in a Chinese salt marsh. Ecol Eng 35:1685-1692

Widdows J, Brinsley M (2002) Impact of biotic and abiotic processes on sediment dynamics and the consequences to the structure and functioning of the intertidal zone. J Sea Res 48:143-156

> Widdows J, Brinsley MD, Salkeld PN, Lucas CH (2000) Influence of biota on spatial and temporal variation in sediment erodability and material flux on a tidal flat (Westerschelde, The Netherlands). Mar Ecol Prog Ser 194:23-37

> Widdows J, Brinsley MD, Pope ND (2009) Effect of Nereis diversicolor density on the erodability of estuarine sediment. Mar Ecol Prog Ser 378:135-143

Submitted: June 14, 2010; Accepted: September 20, 2010 Proofs received from author(s): November 18, 2010 